\title{
The psychiatric effects of COVID-19 thus far: A review of the current literature
}

\author{
Kandis Wright PhD, Ashish Sarangi MD, Yasin Ibrahim MD
}

\begin{abstract}
The novel COVID-19 pandemic is affecting hundreds of countries with increasing cases and deaths. Global social distancing, quarantines, travel restrictions, and cancelations of schools and large gatherings have been instituted to decrease viral spread. This has sparked perpetual worldwide fear, panic, anxiety, depression, and distress along with concern for suicide, grief, post-traumatic stress disorder (PTSD), guilt, and long term mental health disorders. In this paper, we review current literature in PubMed regarding psychiatric effects of COVID-19 on varying populations and what long term mental health effects warrant consideration. In the general public, significant anxiety (6.33-35.1\%) is focused largely on family members and loved ones potentially contracting COVID-19; this fear is associated with female gender, student status, and various age groups, and is exacerbated by social media, self-quarantine, increased time thinking about COVID-19, and misinformation. Self-reported depression ranges from 16.5-48.3\%. Other potential at risk populations include pregnant women, parents, children, the elderly, and patients with pre-existing mental health disorders. COVID-19 has driven suicide and exacerbated obsessive compulsive disorder (OCD). Medical healthcare workers have increased anxiety, depression, distress, and low sleep quality, with frontline female nurses reporting the most symptoms. Patients with COVID-19 have a high prevalence of PTSD, depression, and low quality of life. PTSD, depression, grief, and guilt are of long term concern. Overall, future and continued studies exploring the psychiatric effects of COVID-19 worldwide are critical in understanding and treating affected populations.
\end{abstract}

Keywords: Psychiatric, COVID-19 and mental health symptoms, anxiety, depression, suicide, grief, and PTSD

\section{Coronavirus 2019}

The novel Corona Virus Disease 2019 (COVID-19) caused by Severe Acute Respiratory Syndrome-CoV2 (SARS-CoV2) was declared a pandemic March 11, 2020 , by the World Health Organization. ${ }^{1,2}$ It was initially identified in Wuhan, China, in December 2019 where patients presented with a severe respiratory illness and/or viral pneumonia that was highly contagious. ${ }^{1,3}$

Corresponding author: Kandis Wright

Contact Information: Kandis.Wright@ttuhsc.edu

DOI: 10.12746/swrccc.v8i35.727
Respiratory viruses spread through respiratory droplets when coughing or sneezing; avoiding sick individuals, washing hands, disinfecting environmental surfaces, and reducing travel are crucial to decreasing viral spread. ${ }^{1,4}$ The most common symptoms reported are fever, cough, dyspnea, myalgia, headache, and diarrhea. ${ }^{4}$ COVID-19 positive patients can be asymptomatic carriers, experience a mild illness, or develop fatal complications. ${ }^{4-6}$ Those requiring intensive care support are more likely to be of older age with pre-existing comorbidities, such as respiratory, cardiovascular, cerebrovascular, digestive, and endocrine diseases. ${ }^{4}$ No treatment is available; however, treatment development is the epicenter of current research. 
To slow the spread of COVID-19, the WHO advised circumventing travel to high risk areas, avoiding contact with symptomatic or exposed individuals, increasing basic hand hygiene measures, using of personal protective equipment (PPE), and social distancing. ${ }^{7}$ Many citizens are working from home and schools are closed. Many hospitals lack sufficient PPE and/or ventilators to adequately handle the growing pandemic. Social media is filled with COVID-19 information while businesses and universities are functioning through online resources. Altogether, this has increased self-reported anxiety, distress, depression, and post-traumatic stress disorder (PTSD) symptoms and has even driven suicide. In this paper, recent studies regarding the psychological components of the COVID-19 outbreak are reviewed. The PubMed database was searched for articles pertaining to COVID-19 and mental health, depression, suicide, grief, anxiety, PTSD, fear or distress/stress. Here we focus on the psychiatric effects of COVID-19 on different populations and what long term effects need consideration.

\section{PSYCHIATRIC EFFECTS}

\section{General Population AND the ELDERLY}

Outbreaks can precipitate new psychiatric symptoms, aggravate pre-existing mental illness, initiate fear and anxiety about falling sick or dying, and generate feelings of helplessness and blame for others who are ill. Psychiatric comorbidities, including anxiety, depression, panic attacks, somatic symptom disorder, PTSD, delirium, psychosis, suicidal ideation, and grief have been associated with previous pandemics. ${ }^{8}$ Thus, it is unsurprising that the general public has reported feelings of distress, anxiety, depression, PTSD, insomnia, OCD, and suicide in response to COVID-19 with most published cross-sectional studies from China (Summary Table 1).

In a recent review, $16-28 \%$ of respondents reported anxiety and depression, and $8 \%$ reported stress potentially associated with decreased sleep. ${ }^{9}$ Since then approximately 21 additional studies have been published. Approximately $53.8 \%$ of the Chinese general public reported a moderate to severe psychological impact, $67.7 \%$ began paying more attention to their mental health, and there were decreased positive emotions and life satisfaction following the outbreak. ${ }^{10-12}$ The prevalence of mild to severe anxiety ranged from $6.33-35.1 \%$ with the majority of cases being mild. ${ }^{10,11,13-16}$ Women and people older than 40-years-old displayed a higher likelihood of developing anxiety, while another study reported greater anxiety in those less than 35-years-old who spent increased time thinking about COVID-19. ${ }^{14,15}$ Higher psychological distress was reported in females, people 18-30 and greater than 60-years old along with migrant workers, people in the Hubei region of China, and those with higher education. ${ }^{17}$ Eighteen to 30 -year olds have higher exposure to social media which can trigger stress, while older people have a higher mortality rate due to COVID-19. Relatively low morbidity rates and limited pandemic exposure due to stay at home orders are potential protective effects in younger individuals ( $<18$ years old). ${ }^{13,17}$ Fortunately, lower distress was reported by participants of ages 18-30, 31-40, and greater than 50 -years old who spent more time relaxing and resting; older adults with positive self-perceptions of aging had higher resiliency. ${ }^{12,18}$ These studies suggest possible protective mechanisms to decrease distress. Interestingly, female students had higher levels of anxiety, distress, and/or depression. ${ }^{10,11,16,19,20}$ Most of the anxiety experienced was mild. ${ }^{21}$ Living in urban areas, living with parents, and having a stable family income protected against anxiety, while having a COVID-19 positive relative or acquaintance was a risk factor. ${ }^{21}$ Sudden cessation of the school year, transition to online courses, decreased social interactions, and uncertainty of finishing courses and staying on track are likely contributing factors.

Altogether, studies indicate that reported anxiety is largely focused on family health. ${ }^{10,11,21-23}$ Following the emergence of COVID-19, people expressed increased concern regarding their and their family's health, while worrying less about leisure and friends. ${ }^{10}$ Approximately $75.2 \%$ of Chinese people expressed concern regarding family members contracting COVID-19. In the U.S., a recent poll released by the American Psychiatric Association (APA) found that $62 \%$ of people reported anxiety concerning the potential of family members or loved ones becoming ill and in Spain, higher distress was associated 
with increased contact with non-co-residing relatives. ${ }^{11,19,24}$ Furthermore, there is evidence suggesting that contact with relatives and increased family support improves mental health. ${ }^{12,19,21}$ Decreased contact with relatives correlated with increased loneliness and social support was negatively correlated with anxiety symptoms. ${ }^{19,21}$ The majority of respondents in one study received increased support from family and friends, shared their feelings more "when feeling blue," and cared more for the feelings of family members during COVID-19. ${ }^{12}$ This suggests that anxiety and worry focused on family members' health during the pandemic has resulted in increased communication and support among family members to help ease anxiety and improve mental health.

Self-quarantine, social media, spending $\geq 3$ hours/ day thinking about COVID-19, a lack of information, and fear contribute to elevated anxiety levels. ${ }^{14} \mathrm{~A}$ 14-day self-quarantine revealed anxiety as positively associated with stress and reduced sleep quality and, along with stress, reduced the positive effects of social capital. ${ }^{25}$ By focusing on enhancing social capital, anxiety, stress, and sleep quality could be improved during periods of self-quarantine. Furthermore, using social media increased the adjusted odds ratio of anxiety compared to less exposure and more than $66 \%$ of people reported worry after viewing COVID-19 related social media posts. ${ }^{13,22}$ The highest percentages of reported depressive symptoms were associated with frequent exposure to social media and being less than 35-years old and spending $\geq 3$ hours/day thinking about COVID-19. ${ }^{13,14}$ More than $80 \%$ of the general population was exposed to social media and $93.5 \%$ of people reported the internet as their primary health information source..$^{11,13,22}$ In one study, $22.6 \%$ of the population reported anxiety, $48.3 \%$ depression, and $19.4 \%$ experienced a combination of both, which are higher than the national averages (i.e., $16.6 \%$ anxiety, $7.6 \%$ depression, and $6.9 \%$ both) reported in China prior to COVID-19. ${ }^{13}$ These subjects expressed feelings of anxiety, fear, worry, and nervousness on social media which could potentiate anxiety, depression, and other negative emotions in others. This is likely due to increased viewer exposure, easy accessibility, and emotional responses elicited by posted content. Moreover, increased public indignation was due to dissatisfaction with misinformation from governments and regulatory actions, which is unsurprising as misinformation and uncertainty lead to fear and unease, further threatening mental health stability. ${ }^{10,11}$ Fear can drive feelings of anxiety and unease leading to irrational behaviors, such as hoarding toilet paper, masks, and hand sanitizer, and suicide, stigma, and discrimination following the origination of the outbreak in China. ${ }^{26,27}$ Suicide has been described as a response to anxiety, fear, and misinterpretations of having COVID-19 by individuals and their communities. ${ }^{28,29}$ The effects of COVID-19 on overall suicide rates should be evaluated with future studies.

Reports of mild to severe depressive symptoms have increased since the emergence of COVID19 with a prevalence of $16.5 \%$ to $48.3 \%{ }^{10,11,13-16}$ Of those reporting depressive symptoms, $84.7 \%$ of them spent 20-24 hours at home each day and people without formal education showed a greater likelihood of developing depression. ${ }^{11}$ Improved mental and physical health and life satisfaction was reported by people continuing to work compared to people who stopped working. ${ }^{30}$ Conversely, the severity of COVID-19 correlated with decreased life satisfaction in people with pre-existing medical conditions. ${ }^{30}$ This suggests that staying home for extended periods, having no formal education, not working, and having pre-existing medical conditions may worsen mental health. Furthermore, depression is common in the elderly population. There is a prevalence of depressive symptoms of $23.6 \%$ in older Chinese adults. ${ }^{31}$ This could be compounded with a high vulnerability of contracting and dying from COVID-19 as indicated by high fatality rates in people 70-79 and older than 80 -years old. ${ }^{32}$ Physicians in Italy have to triage and sometimes cease treatment of COVID-19 positive elderly patients due to a lack of resources, and there is a massive quarantine of nursing homes in the U.S. ${ }^{33}$ Due to all these factors, COVID-19 could exacerbate the risk of mental health problems and pre-existing psychiatric symptoms thus potentially impairing cognition and daily function in the elderly.

In patients with OCD, cleaning, washing, and sterilizing compulsions are driven by unwanted intrusive anxiety about being dirty, and the fear of acquiring a new infectious disease, such as COVID-19, can 
worsen these behaviors. ${ }^{34}$ One paper described a previously stable patient with OCD who required additional treatment during the pandemic due to his intense fear of getting infected, avoidance of meeting people, and dysfunctional behavior due to increased hand washing. ${ }^{34}$ Furthermore, agoraphobia, the fear or anxiety of being in situations perceived as difficult to escape or seek help, may be exacerbated as people worry about contracting COVID-19 particularly in public areas. Even among the general population, having an organic disease was a risk factor for developing OCD, insomnia, and depression. ${ }^{20}$

\section{Other At RISK POPULATIONS}

Additional groups of people at risk for developing anxiety and other mental health disorders include pregnant women, parents, and children. Infants and newborns can be infected through inhalation of viral aerosols from coughing and close contact with relatives and healthcare workers. ${ }^{35}$ This raises concerns for pregnant women and the health of newborns. Thus far, there is no current evidence for intrauterine infection of COVID-19 by vertical transmission in women late in pregnancy. ${ }^{36}$ Similarly, the CDC reports that children do not appear to have any higher risk of contracting COVID-19 than adults, but when positive show milder symptoms. ${ }^{37}$ This knowledge can help ease worry and anxiety in expectant mothers and parents. Many parents also could have elevated anxiety and mental health concerns due to changes and new stressors in having to educate and care for their children, to work, and to maintain the home fulltime. Parents with children in the hospital during the pandemic had higher anxiety, depression, and dream anxiety compared to before the pandemic. In this study, the mental health problems of parents during the pandemic were more serious with more obvious symptoms of anxiety and depression. ${ }^{23}$ Thus additional attention and sensitivity to the mental health of parents of sick children should be considered. Approximately 1.38 billion children worldwide are out of school or child care, and between 2012-2015, 35\% of adolescents who received mental health services received them exclusively from school. ${ }^{38,39}$ Without school, some children may not have adequate mental health resources to sustain them during the COVID19 pandemic. Future studies could examine the psychiatric effects of COVID-19 in these populations.

\section{MEDICAL HEALTHCARE WORKERS}

Healthcare workers in isolation wards, intensive care units, and emergency departments have greater risks of developing adverse psychiatric outcomes due to heightened stress, higher levels of depression and anxiety, becoming emotionally affected and traumatized, and fear of transmission to their loved ones. $^{8}$ Of the Wuhan medical and nursing staff 6.2 $36.9 \%$ reported subthreshold, mild, moderate, and severe overall mental health disturbances as identified by overall PHQ-9, GAD-7, ISI, and IES-R scores (Summary Table 1). The majority had mild to moderate mental health disturbances and the more severe distress correlated with extensive exposure to COVID19 and use of fewer psychological resources. ${ }^{40}$ Across multiple studies depression has been reported in approximately $12.2-50.4 \%$, anxiety in $13.0-48.1 \%$, insomnia in $34-38.4 \%$, distress/stress in $39.1 \%-$ $71.5 \%$, and OCD symptoms in $5.3 \%$ of healthcare workers. ${ }^{14,20,41-43}$ This suggests that healthcare workers during the COVID-19 pandemic suffer from a wide range of psychological effects.

Increased depression, anxiety, insomnia, and distress were found among female nurses, and higher stress was positively correlated with long working hours, being an only child, and having higher anxiety levels. ${ }^{43,44}$ The majority of nurses also tend to be female, thus affecting the overall gender results. Furthermore, frontline workers outside Hubei province were associated with a lower risk of experiencing distress compared to those in Wuhan, thus demonstrating that frontline health care workers in the Wuhan COVID-19 pandemic experience increased psychological distress. Sources of distress include concerns about self-health and being infected, health of friends and family, being isolated, shortage of supplies, protective equipment, and personnel, worry that the epidemic would never be controlled, and feelings of vulnerability, loneliness, frustration with unsatisfactory results at work, and loss of control. ${ }^{42,44}$ These findings are unsurprising because the anxiety and fear of 
getting infected are much higher among healthcare workers, especially frontline physicians and nurses having close frequent contact with patients. While the anxiety of the general public focused on losing their family members, it appears that health workers focus more on their family losing them and being responsible for infecting their family members, which negatively affects their willingness to treat COVID-19 patients..$^{43,45}$ Interestingly, one study unexpectedly found that vicarious traumatization (VT), trauma workers affected by interactions and empathic engagements with traumatized patients or patients with mental disease, was higher in the general public and non-front line nurses compared to frontline nurses. ${ }^{41}$ Frontline nurses in this study had more experience and were voluntary compared to non-frontline nurses, indicating that they were likely more readily prepared and willing to handle COVID-19 trauma. Perhaps increased experience, psychological endurance, and volunteering to treat COVID-19 patients are protective factors against VT. Overall, in healthcare workers, being female, living in a rural area, having an organic disease, and being at risk of contact with COVID-19 patients are risk factors for anxiety, depression, insomnia, and somatization. ${ }^{20}$

Sleep quality was relatively low in medical personnel, and healthcare workers reported the highest rate of poor sleep quality especially in those who spent more than 3 hours daily thinking about COVID-19 information. ${ }^{14,46}$ Social support indirectly affected sleep quality by reducing anxiety and stress and improving self-efficacy and individual judgment allowing for specific behaviors that help maintain mental stability and coping skills. Sleep quality is critical for performance and optimal immune function. In surgeons, there were positive correlations between anxiety, depression, and dream anxiety during the outbreak versus the nonoutbreak group, suggesting that sleep disturbances and psychiatric symptoms are impacted by the pandemic. ${ }^{47}$ Overall, a lack of social support, communication, maladaptive coping, and a lack of training have been identified as common risk factors for developing psychological disorders following a disaster; therefore, social support is critical in healthcare settings. ${ }^{8}$

Additionally, $89.51 \%$ of psychiatrists and psychiatric nurses reported extensive knowledge of COVID-19, and significantly more physicians acquired their knowledge from medical journals. ${ }^{45}$ In a longitudinal study, significantly more people of the general public expressed a very high level of confidence in their doctors to diagnose COVID-19. ${ }^{15}$ This is interesting because these parameters increased within a similar time frame (early to mid-April). Perhaps this will have a positive mental health impact because increased knowledge will improve their comfort in diagnosing COVID-19 patients, and increased confidence in providers will ease anxiety and worry within communities. To fully assess and understand the mental health effects of COVID-19, additional studies across various institutions, countries, and medical populations are warranted. Overall, Ho et al. stated clearly that conflict and dissonance in many medical healthcare workers can result from the balance among professional duty, personal fear, and altruism. ${ }^{15}$

\section{COVID-19 PATIENTS}

Only two studies were identified in our PubMed search regarding the psychiatric effects in patients with COVID-19. Patients with COVID-19 symptoms had a higher likelihood of depression and a lower health related quality of life score compared to patients without COVID-19 symptoms which remained true even when both groups had low health literacy scores. ${ }^{48}$ Essentially higher health literacy scores were protective against depression and quality of life in people with COVID-19 symptoms. Post-traumatic stress disorder was found in $96.2 \%$ of clinically stable COVID-19 patients prior to discharge, suggesting substantial distress experienced by these patients. Interestingly the majority of this population were 50 year old men and $49.8 \%$ considered online psych-educational services helpful. ${ }^{49}$ Thus far depression, decreased quality of life, and PTSD are the most prevalent symptoms reported by patients experiencing COVID-19 symptoms. However, additional studies need to be performed in this population to evaluate the short and long term psychological effects of COVID-19.

\section{LONG TERM CONCERNS}

Research on previous outbreaks indicate that emotional reactions are not always short lived but can 
Table 1. Overall Summary Table of Observational Studies of Mental Health Concerns Related to COVID-19 in Various Populations

\begin{tabular}{|c|c|c|c|c|c|}
\hline $\begin{array}{l}\text { Author } \\
\text { Pub Date }\end{array}$ & Study Design & Country & Population & Protocol(s) & Main Result Brief Summary \\
\hline $\begin{array}{l}\text { Lai et al. }{ }^{44} \\
\text { March } 2\end{array}$ & $\begin{array}{l}\text { Cross-sectional, } \\
\text { hospital-based } \\
\text { survey }\end{array}$ & China & $\begin{array}{l}\text { Healthcare workers } \\
(\mathrm{n}=1257)\end{array}$ & $\begin{array}{l}\text { PHQ-9, GAD-7, } \\
\text { ISI, and IES-R }\end{array}$ & $\begin{array}{l}\text { Women, nurses, frontline healthcare workers, } \\
\text { and healthcare workers in Wuhan had higher } \\
\text { severity of depressive, anxiety, insomnia, } \\
\text { and distress symptoms. Frontline healthcare } \\
\text { workers had a higher risk of depression, } \\
\text { anxiety, and insomnia. }\end{array}$ \\
\hline $\begin{array}{l}\text { Wang et al. }{ }^{11} \\
\text { March } 6\end{array}$ & $\begin{array}{l}\text { Cross-sectional, } \\
\text { online } \\
\text { questionnaire }\end{array}$ & China & $\begin{array}{l}\text { General public } \\
(\mathrm{n}=1210)\end{array}$ & $\begin{array}{l}\text { IES-R and } \\
\text { DASS-21 }\end{array}$ & $\begin{array}{l}\text { Moderate to severe depressive } 16.5 \% \text {, anxiety } \\
28.8 \% \text {, and stress } 8.1 \% \text { symptoms. } 75.2 \% \\
\text { worried about family getting COVID- } 19 \\
\text { and being female, a student, having physical } \\
\text { symptoms, and poor self-rated health } \\
\text { associated with stress, anxiety, and depression. }\end{array}$ \\
\hline $\begin{array}{l}\text { Qui et al. }{ }^{17} \\
\text { March } 6\end{array}$ & $\begin{array}{l}\text { Cross-sectional, } \\
\text { online } \\
\text { questionnaire }\end{array}$ & China & $\begin{array}{l}\text { General public } \\
(\mathrm{n}=52730)\end{array}$ & CPDI & $\begin{array}{l}35 \% \text { prevalence of mild to severe distress } \\
\text { with higher psychological distress in } \\
\text { females, people } 18-30 \text { and }>60 \text {-years old, } \\
\text { higher education levels, migrant workers, } \\
\text { and those in Hubei. }\end{array}$ \\
\hline $\begin{array}{l}\text { Li et al. }{ }^{41} \\
\text { March } 10\end{array}$ & $\begin{array}{l}\text { Cross-sectional, } \\
\text { mobile } \\
\text { app-based } \\
\text { questionnaire }\end{array}$ & China & $\begin{array}{l}\text { General public } \\
(\mathrm{n}=214), \text { frontline } \\
\text { nurses }(\mathrm{n}=234) \\
\& \text { non-frontline } \\
\text { nurses }(\mathrm{n}=292)\end{array}$ & $\begin{array}{l}\text { Vicarious } \\
\text { Traumatization } \\
\text { (VT) scale }\end{array}$ & $\begin{array}{l}\text { VT significantly higher in non-frontline } \\
\text { nurses and the general public compared to } \\
\text { frontline nurses }(p<0.001) \text {. }\end{array}$ \\
\hline $\begin{array}{l}\text { Xiao et al. } \\
\text { March } 20\end{array}$ & $\begin{array}{l}\text { Cross-sectional, } \\
\text { online } \\
\text { questionnaire }\end{array}$ & China & $\begin{array}{l}\text { General public } \\
\text { self-isolated for } 14 \\
\text { days }(n=170)\end{array}$ & $\begin{array}{l}\text { PSCI-16, SAS, } \\
\text { SASR, and PSQI }\end{array}$ & $\begin{array}{l}\text { Social capital negatively correlated with } \\
\text { anxiety and stress and positively associated } \\
\text { with quality of sleep. }\end{array}$ \\
\hline $\begin{array}{l}\text { Cao et al. } \\
\text { March } 20\end{array}$ & $\begin{array}{l}\text { Questionnaire } \\
\text { packet }\end{array}$ & China & $\begin{array}{l}\text { College Students } \\
(\mathrm{n}=7143)\end{array}$ & GAD-7 & $\begin{array}{l}21.3 \% \text { of respondents with mild, } 2.7 \% \\
\text { moderate, and } 0.9 \% \text { severe anxiety. } \\
\text { Protective factors living in urban areas, } \\
\text { living with parents, and having a stable } \\
\text { family income while having relatives/ } \\
\text { acquaintances infected with COVID-19 as } \\
\text { risk factors for increased anxiety. }\end{array}$ \\
\hline
\end{tabular}


Table 1. Overall Summary Table of Observational Studies of Mental Health Concerns Related to COVID-19 in Various Populations (Continued)

\begin{tabular}{|c|c|c|c|c|c|}
\hline $\begin{array}{l}\text { Author } \\
\text { Pub Date }\end{array}$ & Study Design & Country & Population & Protocol(s) & Main Result Brief Summary \\
\hline $\begin{array}{l}\text { Bo et al. }{ }^{49} \\
\text { March } 27\end{array}$ & Online survey & China & $\begin{array}{l}\text { Stable COVID-19 } \\
\text { patients before } \\
\text { discharge }(n=714)\end{array}$ & PCL-C & $\begin{array}{l}96.2 \% \text { prevalence of PTSD symptoms } \\
\text { and } 49.8 \% \text { of participants considered the } \\
\text { psycho-educational services provided } \\
\text { online helpful. }\end{array}$ \\
\hline $\begin{array}{l}\text { Kang et al. } \\
\text { March } 30\end{array}$ & $\begin{array}{l}\text { Cross-sectional, } \\
\text { online } \\
\text { questionnaire }\end{array}$ & China & $\begin{array}{l}\text { Medical and } \\
\text { nursing staff } \\
(\mathrm{n}=994)\end{array}$ & $\begin{array}{l}\text { PHQ-9, GAD-7, } \\
\text { ISI, and IES-R }\end{array}$ & $\begin{array}{l}36.9 \% \text { subthreshold, } 34.4 \% \text { mild, } 22.4 \% \\
\text { moderate, and } 6.2 \% \text { severe mental health } \\
\text { disturbances. Those with severe distress had } \\
\text { more exposure to COVID- } 19 \text { and accessed } \\
\text { fewer psychological materials. }\end{array}$ \\
\hline $\begin{array}{l}\text { Wang et al. }{ }^{16} \\
\text { March } 30\end{array}$ & $\begin{array}{l}\text { Cross-sectional, } \\
\text { online } \\
\text { questionnaire }\end{array}$ & China & $\begin{array}{l}\text { General public } \\
(\mathrm{n}=600)\end{array}$ & SAS and SDS & $\begin{array}{l}\text { Mild to severe anxiety } 6.33 \% \text { and } 17.17 \% \\
\text { depression. Positive correlation between } \\
\text { SAS and SDS scores. Females and people } \\
\text { age }>40 \text {-years old with higher risk of } \\
\text { developing anxiety. }\end{array}$ \\
\hline $\begin{array}{l}\text { Nguyen } \\
\text { et al. } \\
\text { March } 31\end{array}$ & $\begin{array}{l}\text { Cross-sectional, } \\
\text { interviews } \\
\text { with printed } \\
\text { questionnaire }\end{array}$ & Vietnam & $\begin{array}{l}\text { Patients with and } \\
\text { without COVID-19 } \\
\text { symptoms } \\
(\mathrm{n}=3947)\end{array}$ & $\begin{array}{l}\text { Short version of } \\
\text { the IPAQ, HLS- } \\
\text { SF12, PHQ-9, } \\
\text { and SF-36 }\end{array}$ & $\begin{array}{l}\text { People with COVID-19 symptoms had } \\
\text { higher likelihood of depression and lower } \\
\text { health related quality of life. Health literacy } \\
\text { protective against depression and health } \\
\text { related quality of life. }\end{array}$ \\
\hline $\begin{array}{l}\text { Zhang et al. }{ }^{12} \\
\text { March } 31\end{array}$ & $\begin{array}{l}\text { Cross-sectional, } \\
\text { online survey } \\
\text { through social } \\
\text { media }\end{array}$ & China & $\begin{array}{l}\text { General public } \\
(n=263)\end{array}$ & $\begin{array}{l}\text { IES, questions } \\
\text { for negative } \\
\text { mental health } \\
\text { impacts, social } \\
\text { and family } \\
\text { support impacts, } \\
\text { and mental health } \\
\text { related lifestyle }\end{array}$ & $\begin{array}{l}13.6 \% \text { mild stressful impact. } 7.6 \% \text { IES score } \\
\geq 26.53 .3 \% \text { did not feel helpless. } 52.1 \% \text { felt } \\
\text { horrified and apprehensive. Most people got } \\
\text { support from family and friends. } 67.7 \% \text { paid } \\
\text { more attention to their mental health. People } \\
18-30,31-40 \text {, and }>50 \text {-years old spending } \\
\text { more time relaxing had lower IES scores. }\end{array}$ \\
\hline $\begin{array}{l}\text { Shi et al. }{ }^{45} \\
\text { April } 4\end{array}$ & $\begin{array}{l}\text { Cross-sectional, } \\
\text { professional } \\
\text { online survey }\end{array}$ & China & $\begin{array}{l}\text { Psychiatrists } \\
(\mathrm{n}=141) \text { and } \\
\text { psychiatric nurses } \\
(\mathrm{n}=170)\end{array}$ & $\begin{array}{l}\text { 33-item survey } \\
\text { assessing } \\
\text { knowledge and } \\
\text { attitudes }\end{array}$ & $\begin{array}{l}89.51 \% \text { had extensive COVID-19 } \\
\text { knowledge. Significantly more psychiatrists } \\
\text { got COVID-19 information from medical } \\
\text { journals. } 77.17 \% \text { willingness to care for } \\
\text { psychiatric patients with COVID- } 19 \text {. } \\
53.09 \% \text { concern about infection of family } \\
\text { and } 48.67 \% \text { self-infection. }\end{array}$ \\
\hline $\begin{array}{l}\text { Lu et al. }{ }^{42} \\
\text { April } 4\end{array}$ & $\begin{array}{l}\text { Cross-sectional, } \\
\text { online } \\
\text { questionnaire }\end{array}$ & China & $\begin{array}{l}\text { Medical staff and } \\
\text { administrative staff } \\
(\mathrm{n}=2299)\end{array}$ & $\begin{array}{l}\text { NRS, HAMA, } \\
\text { and HAMD }\end{array}$ & $\begin{array}{l}\text { Higher fear, anxiety, and depression in } \\
\text { medical staff. Significantly more severe fear } \\
\text { and anxiety in medical staff vs administration. } \\
\text { Working in isolation ward, shortage of } \\
\text { protective equipment, loneliness from } \\
\text { being isolated from loves ones, worry about } \\
\text { infection, and frustration with unsatisfactory } \\
\text { work results contributing factors. }\end{array}$ \\
\hline
\end{tabular}

(continued) 
Table 1. Overall Summary Table of Observational Studies of Mental Health Concerns Related to COVID-19 in Various Populations (Continued)

\begin{tabular}{|c|c|c|c|c|c|}
\hline $\begin{array}{l}\text { Author } \\
\text { Pub Date }\end{array}$ & Study Design & Country & Population & Protocol(s) & Main Result Brief Summary \\
\hline $\begin{array}{l}\text { Zhang et al. } \\
\text { April } 4\end{array}$ & $\begin{array}{l}\text { Cross-sectional, } \\
\text { survey }\end{array}$ & China & $\begin{array}{l}\text { General public } \\
(\mathrm{n}=369)\end{array}$ & $\begin{array}{l}\text { SF-12, K6, and } \\
\text { SWLS }\end{array}$ & $\begin{array}{l}\text { People working at office had better mental } \\
\text { and physical health, less distress, and life } \\
\text { satisfaction, and people working from } \\
\text { home had better mental health compared to } \\
\text { those who stopped working. Not working } \\
\text { associated with lower general health, } \\
\text { mental health, and increased limitations for } \\
\text { physical and emotional issues. }\end{array}$ \\
\hline $\begin{array}{l}\text { Mo et al. }{ }^{43} \\
\text { April } 7\end{array}$ & $\begin{array}{l}\text { Cross-sectional, } \\
\text { online } \\
\text { questionnaire }\end{array}$ & China & Nurses $(n=180)$ & SOS and SAS & $\begin{array}{l}39.1 \% \text { reported stress overload and } 32.19 \% \\
\text { anxiety. Stress and anxiety positively } \\
\text { correlated. Higher stress correlated to long } \\
\text { working hours, being an only child, and } \\
\text { higher anxiety levels. }\end{array}$ \\
\hline $\begin{array}{l}\text { Zhang et al. }{ }^{20} \\
\text { April } 9\end{array}$ & $\begin{array}{l}\text { Cross-Sectional, } \\
\text { online } \\
\text { questionnaire }\end{array}$ & China & $\begin{array}{l}\text { Healthcare workers } \\
(n=927) \text { and non- } \\
\text { medical workers } \\
(n=1255)\end{array}$ & $\begin{array}{l}\text { ISI, SCL-90-R, } \\
\text { PHQ-4 and } \\
\text { PHQ-2 }\end{array}$ & $\begin{array}{l}\text { Higher prevalence of insomnia } 38.4 \% \text {, } \\
\text { anxiety } 13.0 \% \text {, depression } 12.2 \% \text {, } \\
\text { somatization } 1.6 \% \text { and OCD symptoms } \\
5.3 \% \text { in healthcare workers. Having organic } \\
\text { disease, being female, living in rural areas, } \\
\text { and being at risk of contact with COVID-19 } \\
\text { patients were risk factors. }\end{array}$ \\
\hline $\begin{array}{l}\text { Yuan et al. } \\
\text { April } 13\end{array}$ & $\begin{array}{l}\text { Hospital } \\
\text { questionnaire }\end{array}$ & China & $\begin{array}{l}\text { Parents of children } \\
\text { hospitalized during } \\
(\mathrm{EH}, \mathrm{n}=50) \text { and } \\
\text { not during }(\mathrm{NEH} \\
\mathrm{n}=50) \text { epidemic }\end{array}$ & $\begin{array}{l}\text { HADS, VDAS, } \\
\text { and SF-36 }\end{array}$ & $\begin{array}{l}\text { Higher anxiety, depression, and dream } \\
\text { anxiety in EH parents. Positive correlations } \\
\text { between depression vs anxiety, and anxiety } \\
\text { and depression vs dream anxiety in EH } \\
\text { parents. Higher SF-36 scores in NEH } \\
\text { parents. }\end{array}$ \\
\hline
\end{tabular}


Table 1. Overall Summary Table of Observational Studies of Mental Health Concerns Related to COVID-19 in Various Populations (Continued)

\begin{tabular}{|c|c|c|c|c|c|}
\hline $\begin{array}{l}\text { Author } \\
\text { Pub Date }\end{array}$ & Study Design & Country & Population & Protocol(s) & Main Result Brief Summary \\
\hline $\begin{array}{l}\text { Wang et al. }{ }^{15} \\
\text { April } 13\end{array}$ & $\begin{array}{l}\text { Longitudinal } \\
\text { study, online } \\
\text { questionnaire }\end{array}$ & China & $\begin{array}{l}\text { General public } \\
(\mathrm{n}=2071 \text { total; } \\
12101^{\text {st }} \text { survey, } \\
8612 \text { nd survey, } \\
333 \text { both) }\end{array}$ & $\begin{array}{l}\text { National } \\
\text { University } \\
\text { of Singapore } \\
\text { COVID-19 } \\
\text { questionnaire, } \\
\text { IES-R, and } \\
\text { DASS-21 }\end{array}$ & $\begin{array}{l}\text { No changes in stress } 8.1 \% \text {, anxiety } 28.8 \% \text {, } \\
\text { and depression } 16.5 \% \text { at initial outbreak } \\
\text { and } 4 \text { weeks later. Significantly lower IES-R } \\
\text { scores } 32.98 \% \text { to } 30.76 \% \text { after } 4 \text { weeks, but } \\
\text { scores above PTSD cut off }>24 \text {. Physical } \\
\text { symptoms, poor rating of self-health, and } \\
\text { history of chronic illness associated with } \\
\text { higher scores. }\end{array}$ \\
\hline $\begin{array}{l}\text { Losada- } \\
\text { Baltar } \\
\text { et al. }{ }^{19} \\
\text { April } 13\end{array}$ & $\begin{array}{l}\text { Online } \\
\text { questionnaire } \\
\text { available } \\
\text { through social } \\
\text { networks }\end{array}$ & Spain & $\begin{array}{l}\text { General public } \\
(n=1310)\end{array}$ & $\begin{array}{l}\text { Liang and Bollen } \\
\text { Attitudes Toward } \\
\text { Aging Subscale, } \\
\text { adapted APGAR } \\
\text { questionnaire, } \\
\text { Self-Perceived } \\
\text { Burden Scale }\end{array}$ & $\begin{array}{l}48 \% \text { variance of distress and } 33 \% \\
\text { loneliness. Higher distress associated with } \\
\text { younger age, female gender, negative self- } \\
\text { perceptions about aging, low sleep quality, } \\
\text { low perceived self-efficacy, few positive } \\
\text { emotions, and more COVID-19 news } \\
\text { exposure. Higher resiliency in older adults } \\
\text { with a positive self-perception of aging. }\end{array}$ \\
\hline $\begin{array}{l}\text { Huang and } \\
\text { Zhao. }^{14} \\
\text { April } 14\end{array}$ & $\begin{array}{l}\text { Cross-sectional, } \\
\text { web based } \\
\text { broadcast } \\
\text { survey }\end{array}$ & China & $\begin{array}{l}\text { General public } \\
\text { including health } \\
\text { care workers } \\
(n=7,236)\end{array}$ & $\begin{array}{l}\text { GAD-7, CES-D, } \\
\text { and PSQI }\end{array}$ & $\begin{array}{l}\text { Symptoms of anxiety } 35.1 \% \text {, depression } \\
20.1 \% \text {, and sleep quality } 18.2 \% \text {. Highest } \\
\text { anxiety and depressive symptoms in } \\
<35 \text {-year olds spending } \geq 3 \text { hours/day } \\
\text { thinking about COVID- } 19 \text {. Poor sleep quality } \\
\text { in healthcare workers. Worse symptoms and } \\
\text { poor sleep when } \geq 3 \text { hours/day thinking about } \\
\text { COVID-19. }\end{array}$ \\
\hline $\begin{array}{l}\text { Gao et al. }{ }^{13} \\
\text { April } 16\end{array}$ & $\begin{array}{l}\text { Cross-sectional, } \\
\text { online survey }\end{array}$ & China & $\begin{array}{l}\text { General public } \\
(n=4872)\end{array}$ & $\begin{array}{l}\text { SME, WHO-5, } \\
\text { and GAD-7 }\end{array}$ & $\begin{array}{l}48.3 \% \text { reported depression, } 22.6 \% \text { anxiety, } \\
\text { and } 19.4 \% \text { a combination, while }>80 \% \\
\text { reported frequent exposure to social media. } \\
\text { SME positively associated with high odds } \\
\text { ratio of anxiety and both depression and } \\
\text { anxiety, and a high prevalence of mental } \\
\text { health problems during the pandemic. }\end{array}$ \\
\hline
\end{tabular}

Chinese versions of Generalized Anxiety Disorder-7 (GAD-7); Gender for Epidemiology Scale for depression (GES-D); 7-item Insomnia Severity Index (ISI); 22 -item Impact of Event Scale Revised (IES-R)- to evaluate feelings of distress and PTSD; Peritraumatic Distress Index (CPDI); Depression, Anxiety, and Stress Scale (DASS21); Short Form Health Survey (SF-36)- evaluate mental and physical health; Hospital Anxiety and Depression Scale (HADS); Van Dream Anxiety Scale (VDAS); Short Form-12 (SF-12); Kessler Psychological Distress Scale (K6); Satisfaction With Life Scale (SWLS); Symptoms Check List-Revised (SCL-90-R); Patient Health Questionnaire (PHQ-4 or -2); General Self-Efficacy Scale (GSES); Stand for Acute Stress Reaction (SASR); Social Support Rate Scale (SSRS); Vicarious Traumatization Scale (VT Scale); Online Ecological Recognition (OER); Personal Social Capital Scale 16 (PSCI-16); International Physical Activity Questionnaire (IPAQ); Health Literacy Questionnaire 12-item Short Form (HLS-SF12); Social Media exposure (SME); WHO-Five Well-Being Index (WHO-5); and 17-Item Self-reported PTSD Checklist (PCL-C); Pittsburgh Sleep Quality Index (PQSI); Posttraumatic Stress Disorder Checklist for DSM-5 (PCL-5); Posttraumatic Stress Symptoms (PTSS); Publication (Pub); Social Media Exposure (SME). All publications published in 2020. 
be severe and persistent. Post-traumatic stress disorder, depression, grief, and severe guilt are psychiatric disorders that should raise concern. ${ }^{50-52}$ Historically, exposure to trauma is associated with psychological distress and PTSD causing people to demonstrate avoidance behavior, intrusive and hyper arousal symptoms, and irritability leading to poorer quality of life ${ }^{51}$ In a longitudinal study, PTSD was found in $44 \%$ of Severe Acute Respiratory Syndrome (SARS) patients, $10 \%$ of hospital workers in Beijing reported PTSD symptoms, and people working on wards were 2-3 times more likely to develop PTSD. ${ }^{52}$ Post-traumatic stress disorder in previously infected patients and medical workers is not uncommon following infectious outbreaks. In the wake of COVID-19, subjective distress decreased significantly from $32.98 \%$ to $30.76 \% 1$ month following the initial outbreak; however, the scores remained above the cutoff for PTSD $(>24)$ indicating continued levels of distress within the general public. Higher scores were associated with physical symptoms, a history of chronic illness, and poor self-ratings of health status. ${ }^{15}$ Furthermore, a $7 \%$ prevalence of posttraumatic stress symptoms (PTSS) was reported in the hardest hit areas of China 1 month after the COVID-19 outbreak that affected significantly more women than men. Elevated symptoms of PTSD were significantly and positively correlated with decreased sleep quality, nighttime waking, and inability to fall asleep..$^{53}$ In clinically stable COVID-19 patients there was a $96.2 \%$ prevalence of PTSD symptoms prior to hospital discharge. ${ }^{49}$ Therefore, current and long term mental health repercussions may include increased PTSD in patients, the general public, and medical healthcare workers.

Depression, severe grief, and/or guilt can occur after losing loved ones to a pandemic. ${ }^{52}$ Grief can stem from traumatic and sudden losses of loved ones, anger and resentment from the inability to gain closure or save patients, guilt in those that are sick or carriers who transmitted the virus, and depression for things lost. ${ }^{8}$ These mental health disorders can occur in anyone, be short to long-lived, and require varying treatments. Current studies and data will be important to study following the COVID-19 pandemic to access the psychiatric health of varying populations to provide appropriate and timely treatment.

\section{Conclusions}

Current literature indicates that the COVID-19 pandemic has increased the levels of anxiety, depression, and stress in the general public, particularly in females, students, and certain age groups. Contributing factors include social media, misinformation, increased time thinking about COVID-19, and self-quarantine. Increased anxiety is focused largely on family and loved ones. COVID-19 has driven suicide and exacerbated OCD. Pregnant women, the elderly, children, and patients with pre-existing psychiatric disorders may be at risk populations experiencing initial or heightened psychiatric effects. Health care workers have elevated anxiety, distress, and depression, and decreased sleep quality, especially in frontline female nurses. Patients with COVID-19 have a high prevalence of PTSD, depression, and low quality of life. The development and persistence of PTSD, grief, guilt, and depression are long term concerns. Future and continued studies exploring the overall psychiatric effects of COVID-19 worldwide are critical in understanding and treating affected populations.

Article citation: Wright K, Sarangi A, Ibrahim Y. The psychiatric effects of COVID-19 thus far: a review of the current literature. Southwest Respiratory and Critical Care Chronicles 2020;8(35):17-28

From: Department of Psychiatry, Texas Tech University Health Sciences Center, Lubbock, Texas

Submitted: $5 / 6 / 2020$

Accepted: 7/6/2020

Reviewer: Kenneth Nugent MD

Conflicts of interest: none

This work is licensed under a Creative Commons Attribution-ShareAlike 4.0 International License.

\section{REFERENCES}

1. Ashour HM, Elkhatib WF, Rahman MM, et al. Insights into the recent 2019 novel coronavirus (SARS-CoV-2) in light of past human coronavirus outbreaks. Pathogens 2020;9:1-15.

2. Shah SGS, Farrow A. A commentary on "World Health Organization declares global emergency: A review of the 
2019 novel coronavirus (COVID-19)". International journal of surgery 2020;76:128-9.

3. Tang JW, Tambyah PA, Hui DSC. Emergence of a novel coronavirus causing respiratory illness from Wuhan, China. $J$ Infect 2020;80:350-71.

4. Lake MA. What we know so far: COVID-19 current clinical knowledge and research. Clin Med 2020;20:124-7.

5. Lai CC, Liu YH, Wang CY, et al. Asymptomatic carrier state, acute respiratory disease, and pneumonia due to severe acute respiratory syndrome coronavirus 2 (SARS-CoV-2): facts and myths. J Microbiol Immunol Infect 2020;53:404-412.

6. Lillie PJ, Samson A, Li A, et al. Novel coronavirus disease (COVID-19): the first two patients in the UK with person to person transmission. $J$ Infect 2020;80:578-606.

7. Sohrabi C, Alsafi Z, O’Neill N, et al. World Health Organization declares global emergency: a review of the 2019 novel coronavirus (COVID-19). International journal of surgery 2020;76:71-6.

8. Ho CS, Chee CY, Ho RC. Mental health strategies to combat the psychological impact of COVID-19 beyond paranoia and panic. Ann Acad Med Singapore 2020;49:1-3.

9. Rajkumar RP. COVID-19 and mental health: a review of the existing literature. Asian J Psychiatr 2020;52:102066.

10. Li S, Wang Y, Xue J, et al. The impact of COVID-19 epidemic declaration on psychological consequences: a study on active weibo users. Int J Environ Res Public Health 2020;17.

11. Wang $C$, Pan $R$, Wan $X$, et al. Immediate psychological responses and associated factors during the initial stage of the 2019 coronavirus disease (COVID-19) epidemic among the general population in China. Int J Environ Res Public Health 2020;17:2032.

12. Zhang Y, Ma ZF. Impact of the COVID-19 pandemic on mental health and quality of life among local residents in Liaoning Province, China: a cross-sectional study. Int J Environ Res Public Health 2020;17:2381.

13. Gao J, Zheng P, Jia Y, et al. Mental health problems and social media exposure during COVID-19 outbreak. PloS one 2020;15:e0231924.

14. Huang $Y$, Zhao N. Mental health burden for the public affected by the COVID-19 outbreak in China: Who will be the highrisk group? Psychology, health \& medicine 2020:1-12.

15. Wang C, Pan R, Wan $X$, et al. A longitudinal study on the mental health of general population during the COVID-19 epidemic in China. Brain Behav Immun 2020;87:40-48.

16. Wang Y, Di Y, Ye J, et al. Study on the public psychological states and its related factors during the outbreak of coronavirus disease 2019 (COVID-19) in some regions of China. Psychology, health \& medicine 2020:1-10.

17. Qiu J, Shen B, Zhao M, et al. A nationwide survey of psychological distress among Chinese people in the COVID-19 epidemic: implications and policy recommendations. General psychiatry 2020;33:e100213.

18. Asmundson GJG, Taylor S. Coronaphobia: fear and the 2019-nCoV outbreak. J Anxiety Disord 2020;70:102196.

19. Losada-Baltar A, Jiménez-Gonzalo L, Gallego-Alberto L, et al. "We're staying at home." Association of self-perceptions of aging, personal and family resources and loneliness with psychological distress during the lock-down period of COVID-19. The journals of gerontology Series B, Psychological sciences and social sciences 2020: gbaa048.

20. Zhang WR, Wang $K$, Yin L, et al. Mental health and psychosocial problems of medical health workers during the COVID-19 epidemic in China. Psychother Psychosom 2020: $1-9$.

21. Cao W, Fang Z, Hou G, et al. The psychological impact of the COVID-19 epidemic on college students in China. Psychiatry Res 2020;287:112934.

22. Roy D, Tripathy S, Kar SK, et al. Study of knowledge, attitude, anxiety \& perceived mental healthcare need in Indian population during COVID-19 pandemic. Asian J Psychiatr 2020;51:102083.

23. Yuan $\mathrm{R}, \mathrm{Xu} \mathrm{QH}, \mathrm{Xia} \mathrm{CC}$, et al. Psychological status of parents of hospitalized children during the COVID-19 epidemic in China. Psychiatry Res 2020;288:112953.

24. New Poll: COVID-19 Impacting mental well-being: Americans feeling anxious, especially for loved ones; older adults are less anxious [Internet]. APA Newsroom; 2020; March 25 [cited March 29, 2020]. Available from: https://www.psychiatry. org/newsroom/news-releases/new-poll-covid-19-impactingmental-well-being-americans-feeling-anxious-especiallyfor-loved-ones-older-adults-are-less-anxious

25. Xiao H, Zhang Y, Kong D, et al. Social capital and sleep quality in individuals who self-isolated for 14 days during the coronavirus disease 2019 (COVID-19) outbreak in January 2020 in China. Med Sci Monit 2020;26:e923921.

26. Asmundson GJG, Taylor S. How health anxiety influences responses to viral outbreaks like COVID-19: what all decisionmakers, health authorities, and health care professionals need to know. J Anxiety Disord 2020;71:102211.

27. Ren SY, Gao RD, Chen YL. Fear can be more harmful than the severe acute respiratory syndrome coronavirus 2 in controlling the corona virus disease 2019 epidemic. World J Clin Cases 2020;8:652-7.

28. Goyal K, Chauhan P, Chhikara K, et al. Fear of COVID 2019: first suicidal case in India! Asian J Psychiatr 2020;49: 101989.

29. Mamun MA, Griffiths MD. First COVID-19 suicide case in Bangladesh due to fear of COVID-19 and xenophobia: possible suicide prevention strategies. Asian J Psychiatr 2020; 51:102073. 
30. Zhang SX, Wang Y, Rauch A, et al. Unprecedented disruption of lives and work: Health, distress and life satisfaction of working adults in China one month into the COVID-19 outbreak. Psychiatry Res 2020;288:112958.

31. Yang Y, Li W, Zhang Q, et al. Mental health services for older adults in China during the COVID-19 outbreak. Lancet Psychiatry 2020;7:e19.

32. Onder G, Rezza G, Brusaferro S. Case-fatality rate and characteristics of patients dying in relation to COVID-19 in Italy. JAMA 2020;323:1775-1776.

33. Nacoti M, Ciocca A, Eng M, et al. At the epicenter of the Covid-19 pandemic and humanitarian crisis in Italy: changing perspectives on preparation and mitigation. NEJM Catalyst 2020:1-5.

34. Kumar A, Somani A. Dealing with Corona virus anxiety and OCD. Asian J Psychiatr 2020;51:102053.

35. Schwartz DA, Graham AL. Potential maternal and infant outcomes from (Wuhan) coronavirus 2019-nCoV infecting pregnant women: lessons from SARS, MERS, and other human coronavirus infections. Viruses 2020;12:194.

36. Chen $\mathrm{H}$, Guo J, Wang $\mathrm{C}$, et al. Clinical characteristics and intrauterine vertical transmission potential of COVID-19 infection in nine pregnant women: a retrospective review of medical records. Lancet (London, England) 2020;395:809-15.

37. Prevention CDC. Caring for children 2020 [updated March 29, 2020]. Available from: https://www.cdc.gov/coronavirus/ 2019-ncov/daily-life-coping/children.html.

38. Cluver L, Lachman JM, Sherr L, et al. Parenting in a time of COVID-19. Lancet 2020;395:e64.

39. Golberstein E, Wen H, Miller BF. Coronavirus disease 2019 (COVID-19) and mental health for children and adolescents. JAMA pediatrics 2020.

40. Kang L, Ma S, Chen M, et al. Impact on mental health and perceptions of psychological care among medical and nursing staff in Wuhan during the 2019 novel coronavirus disease outbreak: A cross-sectional study. Brain Behav Immun 2020;87:11-17.

41. Li Z, Ge J, Yang M, et al. Vicarious traumatization in the general public, members, and non-members of medical teams aiding in COVID-19 control. Brain Behav Immun 2020.
42. Lu W, Wang H, Lin $\mathrm{Y}$, et al. Psychological status of medical workforce during the COVID-19 pandemic: A cross-sectional study. Psychiatry Res 2020;288:112936.

43. Mo Y, Deng L, Zhang L, et al. Work stress among Chinese nurses to support Wuhan for fighting against the COVID-19 epidemic. J Nurs Manag 2020.

44. Lai J, Ma S, Wang Y, et al. Factors associated with mental health outcomes among health care workers exposed to Coronavirus Disease 2019. JAMA Netw Open 2020;3:e203976.

45. Shi Y, Wang J, Yang Y, et al. Knowledge and attitudes of medical staff in Chinese psychiatric hospitals regarding COVID19. Brain, behavior, \& immunity health 2020;4:100064.

46. Xiao H, Zhang Y, Kong D, et al. The effects of social support on sleep quality of medical staff treating patients with coronavirus disease 2019 (COVID-19) in January and February 2020 in China. Med Sci Monit 2020;26:e923549.

47. $\mathrm{Xu}, \mathrm{Xu} \mathrm{QH}$, Wang CM, et al. Psychological status of surgical staff during the COVID-19 outbreak. Psychiatry Res 2020;288:112955.

48. Nguyen HC, Nguyen MH, Do BN, et al. People with suspected COVID-19 symptoms were more likely depressed and had lower health-related quality of life: the potential benefit of health literacy. J Clin Med 2020;9:965.

49. Bo HX, Li W, Yang Y, et al. Posttraumatic stress symptoms and attitude toward crisis mental health services among clinically stable patients with COVID-19 in China. Psychological Medicine 2020:1-2.

50. Naushad VA, Bierens JJ, Nishan KP, et al. A Systematic review of the impact of disaster on the mental health of medical responders. Prehosp Disaster Med 2019;34:632-43.

51. Tang L, Pan L, Yuan L, et al. Prevalence and related factors of post-traumatic stress disorder among medical staff members exposed to H7N9 patients. Int J Nurs Sci 2017;4:63-7.

52. Taylor S. Psychological Reactions to Pandemics. The psychology of pandemics: preparing for the next global outbreak of infectious disease. 1 ed: Cambridge Scholars Publishing; 2019. p. 1-175.

53. Liu N, Zhang F, Wei C, et al. Prevalence and predictors of PTSS during COVID-19 outbreak in China hardest-hit areas: gender differences matter. Psychiatry Res 2020;287:112921. 